\title{
Parasitism of Phalloceros harpagos (Cyprinodontiformes: Poeciliidae) by Sebekia oxycephala (Pentastomida: Sebekidae) in the headwaters of the Cambé River, Paraná State, Brazil
}

\author{
Almeida, WO. ${ }^{\text {a* }}$, Silva-Souza, AT. ${ }^{\mathrm{b}}$ and Sales, DL. ${ }^{\mathrm{a}}$

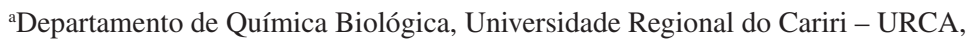 \\ Campus do Pimenta, CEP 63105-000, Crato, CE, Brazil \\ bLaboratório de Ecologia de Parasitos de Organismos Aquáticos, \\ Departamento de Biologia Animal e Vegetal, Universidade Estadual de Londrina - UEL, \\ CEP 86051-990, Londrina, PR, Brazil \\ *e-mail: waltecio@gmail.com
}

Received July 1, 2009 - Accepted August 21, 2009 - Distributed May 31, 2010

(With 1 figure)

Pentastomid species of the family Sebekidae are known to parasitise fish, using turtles and caimans as definitive hosts (Riley, 1986). Species of genus Sebekia have great economic interest as they can cause extensive granulomatous inflammatory reactions with accompanying hemorrhages, myositis, and myodegeneration in cultivated fish (Boyce et al., 1987).

Specimens of Phalloceros harpagos Lucinda, 2008 were collected in February 2002 in the headwaters of the Cambé River (23 $16^{\prime} \mathrm{S}$ and $\left.91^{\circ} 17^{\prime} \mathrm{W}\right)$, municipality of Cambé, Paraná State, Brazil, using gillnets and dipnets.

The captured fish were transported to the Parasites Ecology of Aquatic Organisms Laboratory, Universidade Estadual de Londrina, where they were weighed (total weight in grammes), measured (total and standard length in centimetres), and subsequently submitted to a full necropsy examining the following organs: gills, stomach, intestines, swimming bladder, kidneys, liver, muscles, heart, gonads, eyes and brain.

Pentastomid cysts were removed and opened in order to collect and prepare the parasite nymphs for identification. Part of the sample was fixed in FAA, preserved in $70 \%$ alcohol and mounted on permanent slides in Hoyer's medium. Other specimens were fixed in $2 \%$ glutaraldehyde, $2 \%$ paraformaldehyde and $0.1 \mathrm{M}$ cacodylate buffer, post-fixed in $1 \%$ osmium tetroxide, dehydrated in an increasing ethanol series, dried to the critical point, gold-coated at $25 \mathrm{~nm}$ thickness and examined using a FEI Quanta 200 scanning electron microscope in the Electron Microscopy and Microanalysis Laboratory, PROPPG, Universidade Estadual de Londrina.

Pentastomid identification was based on the dimensions of their hooks, the copulatory spiculae of the males (measured with the aid of an optical microscope fitted with a micrometer eyepiece), the number of body rings and the oral cadre.

We sampled a total of 79 specimens of $P$. harpagos, including 55 adult females (mean total length $2.95 \pm 0.1$ and mean standard length $=2.29$ ) and 24 adult males (mean total length $2.16 \pm 0.1$ and mean standard length $1.79 \pm 0.1)$.

Analyses of the fish demonstrated that five females (mean Lt 3.0 \pm 0.0 and mean Ls $2.2 \pm 0.2$ ) were infected by nymphs of Sebekia oxycephala (Figure 1), which were encysted on the mesentery and the intestinal walls (prevalence $6.3 \%$, mean infection intensity $3.2 \pm 1.6$, range 1-8). No other alteration of the infection sites, beyond the presence of the cysts, was noted during the necropsy.

Junker et al. (1998) reported prevalence between 9.2\% and $40.5 \%$ for cichlid fish in the Kruger National, South Africa. In Brazil, Campos et al. (2008) reported that $8.8 \%$ (3/34) of the specimens of Pseudoplatystoma fasciatum (Linnaeus, 1766) from the Aquidauana River have from one to seven larvae (mean infection intensity 3.3) of an as yet unidentified pentastomid on their mesentery. These values are similar to those of $S$. oxycephala in $P$. harpagos as presented in the present work. On the other hand, Guidelli et al. (2003) reported the occurrence of two specimens of

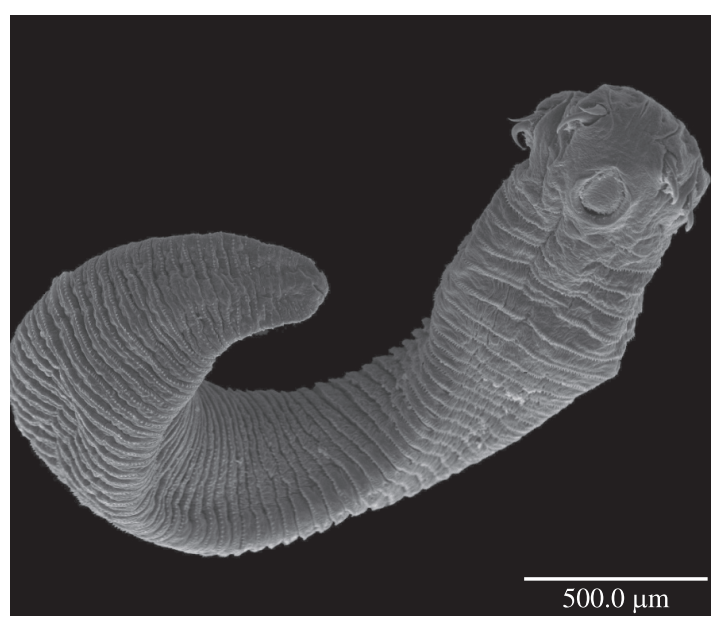

Figure 1. Electron micrograph of entire body in ventral view nymph of Sebekia oxycephala from the mesentery of Phalloceros harpagos (100x). 
Hemisorubim platyrhynchos (Valenciennes, 1940) from the Baia River (on the flood plain of the upper Paraná River in Brazil), with a single cyst each of Sebekia sp. on their mesentery (prevalence 1.5\%, 2/136).

Sebekia oxycephala is widely distributed, occurring from the southern part of the United States to southern South America, and like all of the pentastomid species studied so far in Brazil, it appears to be a generalist parasite species. S. oxycephala had previously been recorded infecting Serrasalmus nattereri Kner, 1860 and Pseudoplatystoma corruscans (Spix and Agassiz, 1829) (Rego and Eiras, 1989), and is now reported for the first time in P. harpagos.

Acknowledgements - We are grateful to CONFEPAR-Cooperativa Central Agro-Industrial Ltda, Londrina, Paraná, for financial assistance, to the Fundação Cearense de Apoio ao Desenvolvimento Científico e Tecnológico-FUNCAP for the productivity fellowship awarded to WO. Almeida (BPI-0112-2.05/08); to the Brazilian National Research Council - CNPq for support through a PIBIC scholarship for DL. Sales. The experiments described here comply with current Brazilian regulations

\section{References}

BOYCE, WM., KAZACOS, EA., KAZACOS, KR. and ENGELHARDT, JA., 1987. Pathology of pentastomid infections (Sebekia mississippiensis) in fish. Journal of Wildlife Diseases, vol. 23, no. 4, p. 689-692.
CAMPOS, CM., FONSECA, VE., TAKEMOTO, RM. and MORAES, FR., 2008. Fauna parasitária de cachara Pseudoplatystoma fasciatum (Siluriforme: Pimelodidae) do rio Aquidauana, Pantanal Sul Matogrossense, Brasil. Acta Scientiarum, Biological Sciences, vol. 30, no. 1, p. 91-96.

GUIDELLI, GM., ISAAC, A., TAKEMOTO, RM. and PAVANELLI, GC., 2003. Endoparasite infracommunities of Hemisorubim platyrhynchos (Valenciennes, 1840) (Pisces: Pimelodidae) of the Baía River, upper Paraná River floodplain, Brazil: specific composition and ecological aspects. Revista Brasileira de Biologia = Brazilian Journal of Biology, vol. 63, no. 2, p. 261-268.

JUNKER, K., BOOMKER, J. and BOOYSE, DG., 1998. Pentastomid infections in cichlid fishes in the Kruger National Park and the description of the infective larva of Subtriquetra rileyi n. sp. Onderstepoort Journal of Veterinary Research, vol. 65 , no. 3 , p. $159-167$

REGO, AA. and EIRAS, J., 1989. Identificação das larvas de Sebekia e Leiperia (Pentastomida). Histopatologia em peixes de rios. Revista Brasileira de Biologia = Brazilian Journal of Biology, vol. 49, no. 2, p. 591-595.

RILEY, J., 1986. The biology of pentastomids. Advances in Parasitology, vol. 25, p. 45-128. 